\title{
The origin and date of 2 Clement.
}

By Vernon Bartlet, Oxford.

It is obvious that, if we could attain assurance as to the date and provenance of this, our earliest Christian homily, it would gain immensely in value to the historian. Not only would it add a significant page to our meagre records of local church history in the second century; it would also cast a clearer light upon not a few other documents with which it is related, though at present all too vaguely. In a recent paper in this Journal, ${ }^{x}$ Prof. Harnack has argued afresh for its Roman origin, and even for bishop Soter (c. 166-174) as its author. Accordingly it is perhaps due to him that I start my own contribution to the problem by referring to two statements of his in defence of his theory, one positive, the other negative.

Harnack asserts that the relation between 2 Clement and Justin's First Apology is such as to exclude a date for the former prior to c. 150 A. D. I assume with him that the phenomena point to literary dependence on the one side or the other; but differ from his view that Justin is prior. The resemblances in question are between I Apol. 53 and the opening sections of the homily. They centre in the quotation

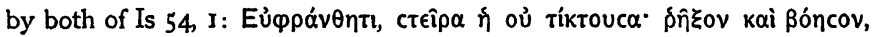

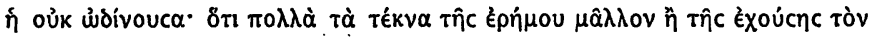

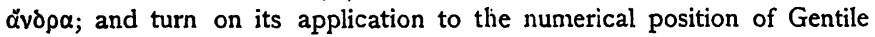
Christianity as compared with Judaism (2 Clem.) and Judaic Christendom (Justin) respectively. Harnack infers that Justin's application is the earlier; 'Soter $(r=2$ Clem.) aber kann schon einen Schritt weiter gehen und behaupten, die Heidenchristen seien bereits zahlreicher als die Juden'. His reason for so judging is simply hinted, as follows: 'Für Justin, der aus Palästina stammte, ist noch der Unterschied von Judenund Heidenchristen von hoher Bedeutung; der römische Bischof sieht

$=$ Vol. VI, pp. $67-71$. 
von diescm Unterschiede ab und stellt vielmehr die Heidenchristen und die Juden sich gegenüber. Dies bezeichnet auch einen großen Fortschritt in dem Wachstum der Heidenkirche; sie erscheint nicht nur zahlreicher als die Judenchristen, sondern sogar zahlrcicher als die Juden.'

I say nothing about the reason suggested for reference to Jewish Christians in the one case and the absence of such reference in the other. It remains quite problematic, as there is another explanation at least equally good which points the other way. Justin's reference is exegetically the more natural one, as preserving the parallelism of the passage cited, which itself contrasts the issue of the barren type of humanity (the Gentiles, called proleptically the Gentile 'Church' or 'people' $\lambda \alpha \sigma 6$ ) with the issue of the married type of humanity (the Jews)which latter should of course mean Jewish-Christians. Hence it is a priori preferable view, that the looser or wilder exegesis of the homilist is on this very account the earlier, rather than that; having the more accurate exegesis before him, he deliberately substituted for it one of a more arbitrary kind. The likelihood depends, indeed, upon the sort of motive he had for such a substitution. And it is here that Harnack's view seems to fail most signally. His argument requires us to assume that during the fifteen or tiventy years which he places between Justin's Apology and 2 Clement, Gentile Christians had so increased in numbers that the homilist felt it no longer enough to describe them as more than Justin's relatively few ( $6 \lambda$ iror $\tau$ tivec) believers sprung from the whole mass of Jews and Samaritans, but proceeded to claim that they were actually more than the Jewish people at large. Surely this is quite incredible. The real explanation of this daring paradox is that the homilist simply fell into it under the suggestion of the text on which - he was commenting, taken in a loose way; and this we have shown he could hardly have done with Justin's more exact exegesis before him. Thus not only does Harnack's argument here crumble to pieces, but the phenomena to which he calls attention become a fresh argument for the priority of 2 Clement to Justin's Apology, ${ }^{1}$ and so go against Soter's authorship. In a word, his positive argument for a date later than Justin really tells the other way.

$x$ There are other features of the passage in Justin which point the same way, e. $\mathrm{g}$. the extra reference to the more genuine piety of Gentile believers, $\pi \lambda \in$ eiovoic $\tau \in$ kai

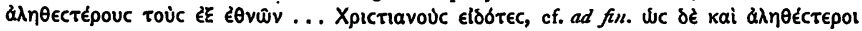

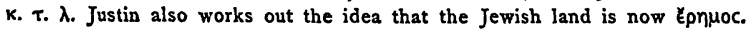


His negative thesis, in defence of his position, is to the effect that no sure criteria have yet been produced pointing to an origin for 2 Clement prior to $150 \mathrm{~A}$. D. Of course, certainty in such matters is a relative term; but the two following indications seem each to be fairly conclusive, and in their combination completely so.

I) The use of the Gospel according to the Egyptians in our homily. This may be taken as practically certain; at any rate it is considered so by Harnack and most other scholars. The proof of this rests ultimately on the passage in ch. 12, agreeing closely with one quoted by Clemens Alex. as cited by the Encratite Cassian from that Gospel. But with this clue in hand, it is natural to refer to the same source those evangelical quotations also which depart considerably from the language or thought of our canonical Gospels (von Schubert, in Hennecke's Handbuch zu den N. T. Apokry'phen, p. 252,-specifies 4, 5. 5, 2 ff. 8,5 as primary cases, and $3,2.4, I(6,1)$ and 13,4 as secondary ones). But can it be seriously maintained that such public use of an apocryphal Gospel peculiarly Egyptian in origin and purpose-a Gospel not even referred to by Irenaeus (so far as extant), and in the West noticed only by the learned Hippolytus in a depreciatory way, in connexion with the Naassenes (Philos. V, 7, p. 136)-is likely to have been made in Rome as late as c. 166-174, and that on an occasion when a preacher's authorities needed to be above suspicion? Credat Fudaeus Apella, to use Harnack's own phrase. This argument, which tells heavily against so late a date, tells also against either Rome or Corinth as churches before which our homily was delivered at any date. For we have no independent evidence that the Egyptian Gospel was ever read publicly outside Egypt. But unless it was so read, and that fairly often, the conditions of our problem would not be satisfied, seeing that it is alluded to without being named, as though to name it before the audience which the preacher was facing were superfluous. It must have been the local Gospel par excellence, standing in general use side by side with two or more of the Synoptic Gospels at least, upon which it was itself probably based. Need one add that this could be true of only one church known to us, viz. that of Alexandria, and there only at a rather primitive period?

2) But the case for a date before 150 and for Alexandrian provenance might safely be staked on a single passage in the homily, that in which the doctrine of the pre-mundane pneumatic Church (ch. 14) is

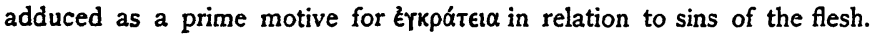


In order to exclude personal bias from our exposition of this famous section, we will first quote the preacher's words and then append the comments of von Schubert (op. cic. p. 253). " $\Omega c t \epsilon, ~ d . \delta \in \lambda \varphi 0 i, \pi 0 t 00 v \tau \tau \epsilon$

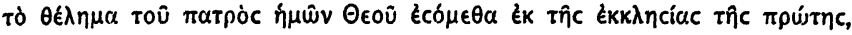

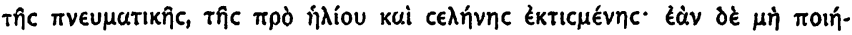

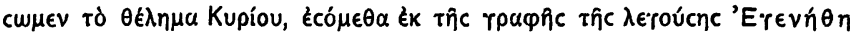

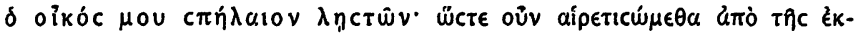

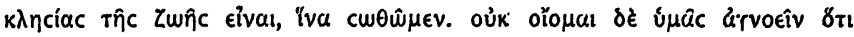

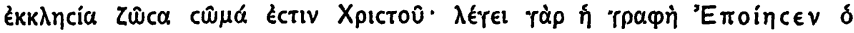

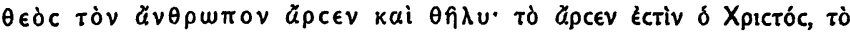

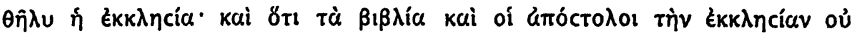

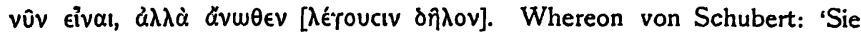
(die Begründung) schliebt an die Spekulationen vom präexistenten pneumatischen Christus als dem himmlischen Menschen oder Adam an, die schon vorher 9,5 anklangen, und erinnert an die gnostisch-valentinianische Vorstellung des Aeonenpaars (der Syzygie) Mensch und Kirche

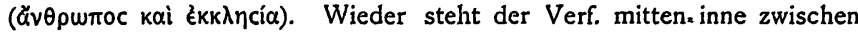
den paulinischen und den gnostisch-häretischen Aussagen, trägt aber seine gnostisierende Meinung naiv vor. Derartiges, nachdem die gnostische und speziell valentinianische Krisis über Rom (und Korinth) hinweggezogen war, in einem offiziellen Schreiben des röm. Bischofs Soter an den spezifisch 'katholisch' gerichteten B. Dionysius, den eifrigen Bekämpfer : der Häresie, enthalten zu denken, scheint unmöglich.' To con-

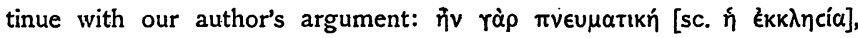

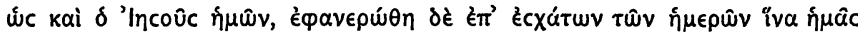

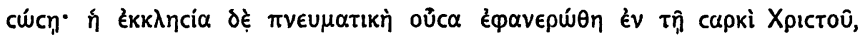

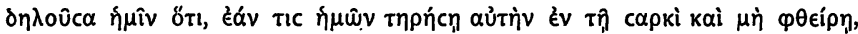

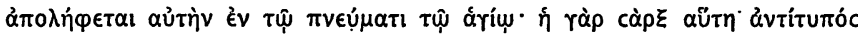

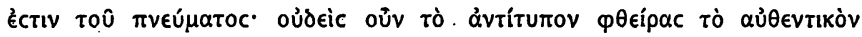

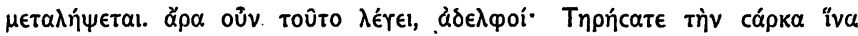

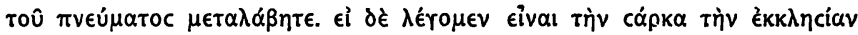

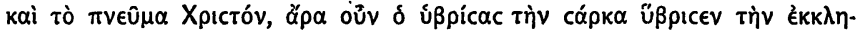

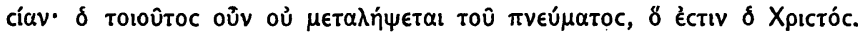

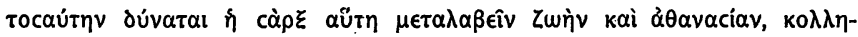

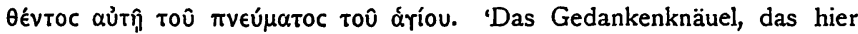
vorliegt, wird so $\mathrm{zu}$ entwirren sein: die eigentlich geistliche Kirche ist ebenso offenbar geworden, wie der eigentlich geistliche Christus, bei ihrer innigen Verbindung mit ihm ist ihre Offenbarung nicht unabhängig von der seinigen, sie ist in seinem Fleische offenbar geworden, ja als 
sein Leib war sie geradezu sein Fleisch. Wie nun Christus (nach Eph. 5, 26f.) diesen seinen Leib oder sein Fleisch, die Kirche, untadelig darstelit, ihr innerer geistlicher Charakter und seine Verbindung mit ihr intakt bleibt; so sollen auch wir an unserem Teil die Kirche untadelig bewahren und damit auch unsere innere, geistliche Verbindung mit der wahren, geistlichen Kirche: was wir, 'im Fleische' bewahren, sollen wir 'im h. Geiste' empfangen. Dieser Gegensatz bringt den Prediger auf eine doppelte Spekulation, um zu begründen, wie das eine durch das andere bedingt ist, I) platonisch: das Fleisch ist Gegenbild des Geistes,

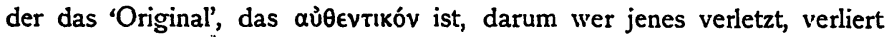
dieses; 2) mystisch-gnostisierend 14, 4: tatsächlich ist aus der paulinischen Fassung des Verhältnisses von Christus zur Kirche als des Hauptes zum Körper die als des Geistes zum Fleische geworden. Das wird aufgegriffen ('wenn wir aber sagen' etc.) und in mystischer Parallele auf uns gewendet: wer sein Fleisch verletzt, verletzt die Kirche, und bei der so engen Verbindung zwischen Fleisch und Geist, Kirche und Christus, auch Geist und Christus ... Zu bemerken ist noch, daß der hl. Geist, wie Harnack richtig bemerkt, als besondere Hypostase überhaupt nicht gefaßt wird, er ist teils Christus selbst, teils der von ihm ausgehende Lebensgeist. - In dem ganzen Kapitel von der 'Kirche' erinnert nichts an die sich bildende 'Katholische Kirche' mit ihren Heilsvermittungen.'

It is quite immaterial whether one accepts in toto this exposition of the preacher's meaning or not; the conclusions to be drawn from the passage remain unaffected. Von Schubert has drawn one of them himself, that which excludes Harnack's date. But the other is no less certain, when once we seriously put to ourselves the following question. Remembering the practical and unidealistic temper of the Roman Church, can we imagine an address moving in such an atmosphere of Platonic idealism-subtle to the point of obscurity and passing rapidly from one nuance of the term $\pi v \in \hat{u} \mu \alpha$ to another-being delivered by a Roman bishop c. 166-174 to his own flock, and then being sent as an edifying moral exhortation to a sister church, for it to make what it might of such argumentation, at a time when the air was charged with Valentinian aeonology? Only one answer is possible when we apply. our imagination to the situation. But we may go further, and setting finally aside the idea of a date after 150, boldly assert that at no date during the second century, or indeed later, can we imagine such an address being delivered to the Roman church by 
a representative man.' Nor is it really much easier to imagine the homily as preached to the Corinthian church, especially when we bear in mind what has been said as to the kind of familiarity with the Egyptian Gospcl presupposed by it. We must remember that 2 Clement was not written for a select circle of cducated readers, but for delivery coram populo in church. This being so, the Platonic cast of this chapter,

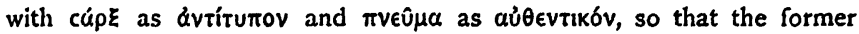
$s$ the manifestation of the latter in the inferior order of the sensible, would surely be ill-adapted to its highly practical object, as at the heart of an earnest moral exhortation, even in Corinth. Only in one church can we imagine such a sermon as really in correspondence with its mental environment; and that is the church at Alexandria. Once we so envisage it, all becomes natural. The only wonder is that this should not have been felt long ago, in connexion even with the date ${ }^{2}$ which on other grounds seems most probable for it, viz. c. 120-140, as Lightfoot has sufficiently shown. No doubt the external evidence has helped to obscure things; yet need lessly, as we shall try to show.

But let us first test our results a little further by internal criteria. Many of the homily's ideas and phrases claim affinity with the East rather than the West. This is notably the case with the final Doxology, in which the characteristic theology of its author appears to an

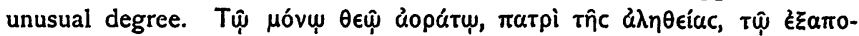

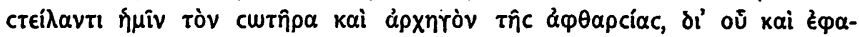

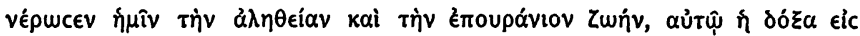

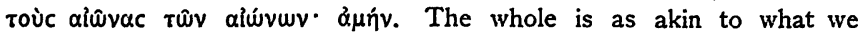
know of the Alexandrine type as it is unlike the Roman, particularly

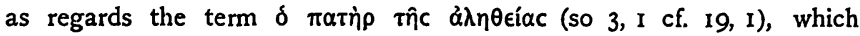
occurs again and again in Sarapion's Prayer-book, an Egyptian work and no doubt ultimately Alexandrine. Then the conception of Christ as the Saviour, especially as inaugurator of immortality and medium of the manifestation of the truth and the heavenly life, reminds us at almost every point of Barnabas and the Eucharistic Prayers ${ }^{3}$ of the Didache,

$x$ In this connexion we may remind ourselves of the significant fact that no Latin version of this homily is known to have existed.

2 I do not forget that Hilgenfeld has suggested Clemens Alex. as its authora theory which so far supports the one here put forward, as rightly gauging the spirit and affinities of our homily. But so late a date alone rules it out of court, e. $g$. in view of the Evangelical quotations. in 2 Clem., as contrasted with and Clement's own attitude to the Gospel according to the Egyptians.

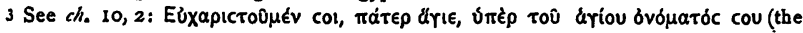
18. 5 . 1906. 
which are both markedly Eastern. Yet it is to the general cast of the Doxology that one can appeal most confidently. Further the references to 'this flesh', over against an incipient tendency to deny its resurrection and so to regard its behaviour as indifferent, belong to the atmosphere of Alexandrine spiritualism for more than to Roman realism. This appears, for instance, from Hermas' way of meeting somewhat similar tendencies to moral laxity, which is far more concretely 'practical, and does not contemplate such subtle apologies for sins of the flesh, at least to any great extent. $x$

It is time, however, that we dealt with the connexion of Hermas and our homily; which is obviously a close one, so close as to argue literary dependence on one side or the other. A priori one would be inclined to regard Hermas as the borrower, in view of his ascertained tendency to use other writings without any formal sign of so doing (e. g. in the case of the Two ways, and probably of the Didacke as a whole). But the point can perhaps be settled on two prominent issues arising out of the chapter already quoted from our homily. 1) In Hermas, Vis. II. 4, $I$, we read as to the guise in which the Church appears to

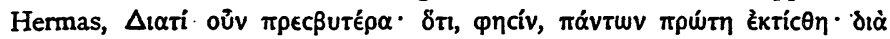

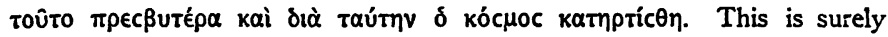
an echo of 2 Clem. I4, I, where the homilist goes on to ground this view in a mystic exegesis of Gen 1,27 , supported by reference to the $O$. T. scriptures and the Apostolic writings, as implying a pre-existent, pnetunatic Church. Hermas quietly appropriates the idea more suo. ${ }^{2}$

2) The Christology of our Homily connects it with Alexandria as decisively as it dissociates it from Rome. The prime criterion in the one case is the Epistle of Barnabas, and in the other the Shepherd of Hermas. No one has put the data for the conclusion we are drawing

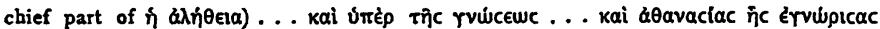

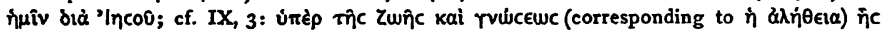
Ervilipicac, $x$. $\tau$. $\lambda$.

I Even if we should see in the men described in Sim. IX, 19, 3 who vitexpiencav

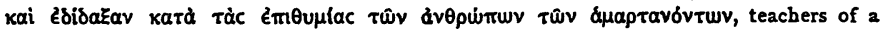
theoretic dualism, yet such a tendency obviously bulked less on Hermas' horizon in Rome than on that of our homilist. It is even possible, in the light of what follows, that Hermas may here be echoing the more explicit statements in 2 Clement.

2 A parallel to this is afforded by the probability made out by Reitzenstein in his Poimastdres, II ff., esp. 34-36, that Hermas obtained his imagery of the Shepherdinstructor from some of the Egyptian Hermetic literature. That Alexandria and Rome stood in very close literary relations, and not least in Christian circles, there is good reason to believe; and this makes Hermas' use of $2 \mathrm{Clem}$. the more likely.

Zeitschr. f. d. neutest. Wiss. Jahrg. VII. 2906. 
on this point more clearly and incisively than Harnack himself. In his History of Dogma he says that the 'diverse conceptions of the Person, that is, of the nature of Jcsus', current in primitive Christianity in a large sense, 'may be reduced collectively to two. Jesus was either regarded as the man whom God had chosen, in whom the Deity or the Spirit of God dwelt, and who, after being tested, was adopted by God and invested with dominion (Adoptian Christology); or Jesus was regarded as a heavenly spiritual being (the highest after God), who took flesh, and again returned to heaven after the completion of his work on earth (Pneumatic Christology). These two Christologies, which are strictly speaking mutually exclusive-the man who has become a God, and the Divine being who has appeared in human form-yet came very near each other when the Spirit of God implanted in the man Jesus was conceived as the pre-existent Son of God, and when, on the other hand, the title Son of God for that pneumatic being was derived only from the miraculous generation in the flesh; yet these both seem to have been the rule. Still, in spite of all transitional forms, the two Christologies may be clearly distinguished. Characteristic of the one is the development through which Jesus is first to become a Godlike Ruler, ${ }^{x}$ and, connected therewith, the value put on the miraculous event at the baptism; of the other, a naive docetism. ${ }^{2}$ For no one as yet thought of affirming two natures ${ }^{3}$ in Jesus; either the divine dignity appeared rather as a gift, or the human nature (cápz) as a veil4 assumed for a time or as the metamorphosis of the Spirit'.

Now Hermas' Christology appears most distinctly in Sim. V. relating to the Faithful Servant. This Servant, here defined on his

$x$ 'Hermas has the thing (i. e. Oeoroincic) itself quite distinctly'.

2 Harnack says this 'plainly appears' in Barn (5 and 12). But he overlooks the fact that it is at least as clear in 2 Clem. 9, 5 El 'Incouc (cf. Lightfoot ad loc.) Xpictóc,

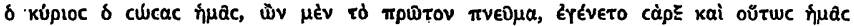

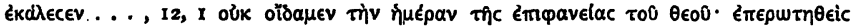

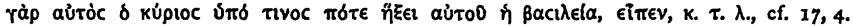
Then later in Clem. Alex., as Harnack says, 'in spite of all his polemic against dókncıc proper, one can still perceive a "moderate docetism".' It is in fact most characteristic of Alexandria. See also note 4.

3 'For this requires, as its presupposition, the perception that the divinity and humanity are equally essential and important for the personality of the Redeemer Christ.'

4 So Barnabas, says Harnack-adding that 'to this conception corresponds the formula epXec $\theta$ al (

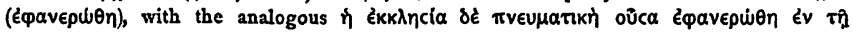
capki Xpictoo. 
servile or distinctively human side as cáp乏 chosen of God, having

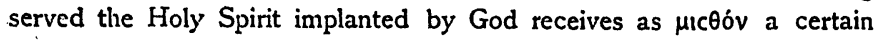
abiding-place, described in the parable itself as the status of co-heirship

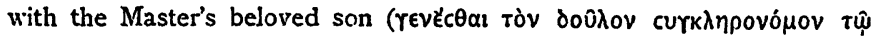
vị̂̂ aủroo (Sim. V, 2, II)-in another connexion (Sim. IX, I, I) defined as the Holy Spirit. ${ }^{x}$ That is, the seat of personality or will, as we should say, is conceived by Hermas to lie in the lower or human nature of the historic Christ, which by exercising its will aright, in

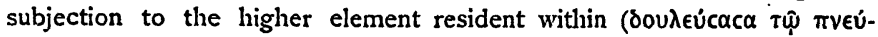

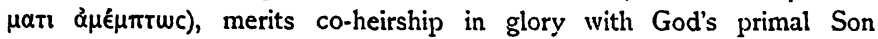
or Holy Spirit. This is an essentially 'adoptian' standpoint, and it runs through Hermas' thought, as when he exhibits the Servant's conduct as

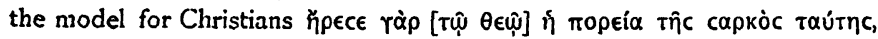

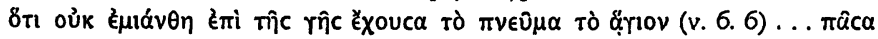

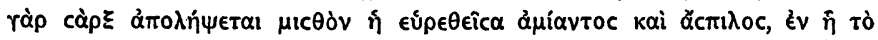
$\pi v \in \hat{u} \mu \alpha$ tò ärıv katẃkncev (ib. 7, cf. 7,1 ). The analogy between Christ's purity and that of the Christian reminds one enough of $2 \mathrm{Clem}$. 14, 3 to make us infer Hermas' dependence. But all the more we notice the difference of the homilist's Christology. He makes the

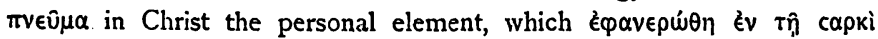
X the metamorphosis of the Spirit'. His standpoint is essentially 'pneumatic', and even the cóp $\rho \xi$ is conceived in the sublimated fashion proper to Alexandrian Platonism, as antitype of the spirit which determines it. His affinity with the Alexandrine Bamabas is as marked as is the contrast to the Roman Hermas, who has taken as much from 2 Clem.

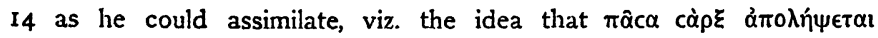

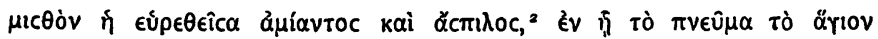

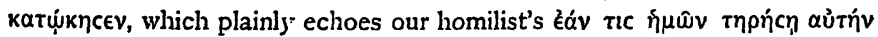

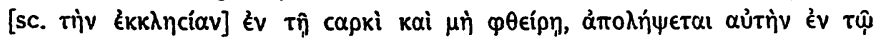
$\pi v \varepsilon \cup \operatorname{uan}$ Tफ̣ árị. Much in the accompanying argument is ignored by Hermas, as not in terms of his own thinking-unless indeed we distinguish two stages in Hermas' thought, the latter of them being represented by the Christology of Sim. IX. I2, I-3. There the same Son of God appears in two aspects or relations, first as prior to all

I Cf. Harnack, op. cit. I. 193n'; In Hermas the real substantial thing in Jesus Christ is the capz?.

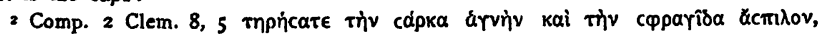

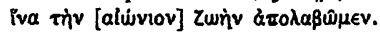


creation (the rock on which the Church is built), and next as En' Exxa-

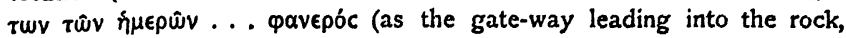
through which the saved enter into the kingdom). This recalls 2 Clem.

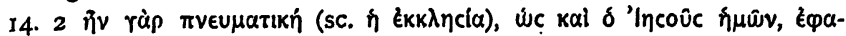

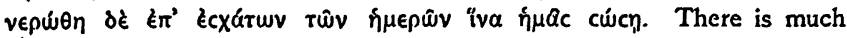
reason to regard Sim. IX as belonging to a later stage in Hermas' prophetic ministry than Sim. V, when perhaps he had come to adopt more of the standpoint of the 'pneumatic' Christology, which made

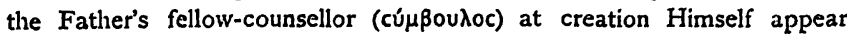
on earth, and not merely a mode or portion of this Holy Spirit, such as 'dwelt' also in humanity ( $(\alpha ́ p \xi)$ generally (as in Sim. V). But in any case we cannot imagine 2 Clement's 'pneumatic' Christology and Ecclesiology, in ch. 14, dependent upon Hermas' diffuse, allusive, and figurative discussions; the dependence, so far as it exists at all, is the other way, though the works really belong to different local theological traditions, the one Alexandrine, the other Roman.

This relation is further confirmed by 3) their respective teaching on $\mu \dot{e} \tau a ́ v o ı$. 2 Clem. makes an urgent call for repentance while men

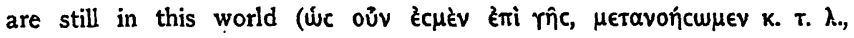
ch. 8), without reference to any limit as to repetition; but a distinctive point in Hermas' message is that only one repentance for the baptized is possible, and that by special allowance, some holding that not even this is open (Mand. IV, I and 3). This being so, while Hermas may well have known our homilist's teaching on the matter, 2 Clem. could not have expressed himself as he does, were the prophetic message of Hermas known to him and his hearers. In all respects, then, Hermas witnesses both that 2 Clem. was prior to the publication of his own work, and that it originated in another church than that of Rome.

When we try to test the conclusions that have emerged again and again in our discussion of special pieces of internal evidence, viz. that our homily belongs to Alexandria and to the period c. 120-140, the result is altogether favourable, so far as the scanty evidence goes. Its affinities with Barnabas are manifest; and as we have seen, its fundamental conceptions have marked points of contact with the Eucharistic prayers of the Didache. ${ }^{x}$ The same is true of the earliest pseudo-Petrine writings, the Preaching and Apocalypse of Peter, both traceable to Alexandria and possibly to c. 125 .

I Compare also XIII, 4, XVI, 4 with Did. I, 3, 5 ; XVII, 3 f. with Did. XVI, If. 
The resemblances to the former are not only in slight turns of

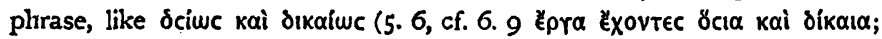

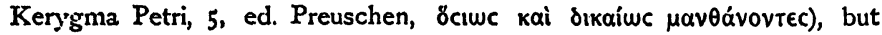

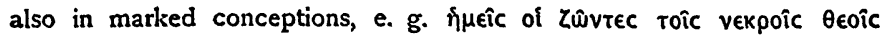

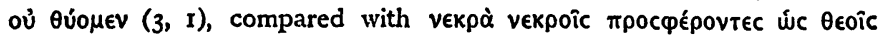

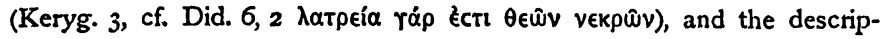

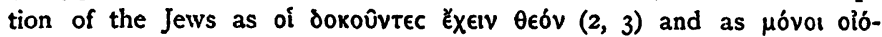

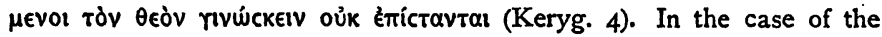
Peter Apocalypse we have such affinities as are furnished by references to the Day of Judgment as involving the melting of 'certain of the heavens' ( 16,3 , cf. Frag. ap. Macarius Magnes, Preuschen, p. 52), and to the penalties of the unfaithful in contrast to the well-being of the righteous (17, 3-5, cf. Akhmim Frag. generally). Observe too the naive religious way in which both refer to the action of God and of Christ as synomymous. In the Apocalypse we find 'the Lord' saying, 'And then shall God come to my faithful ones ... and shall judge the sons of lawlessness' (ad init.); while in 2 Clem. I2, I we read that 'we know not the day of the Epiphany of God'. Thus we feel ourselves in the same rather special atmosphere in all three works; and it is that of Alexandria, to which the two Petrine works almost certainly belong; nor should we overlook the fact that Peter appears as the spokesman in the apocryphal Gospel cited in 2 Clem. $5,3$.

Finally to yet another witness we may turn for further proof that the Christology of our homilist is Eastern in its affinities. In the Acta Pauli

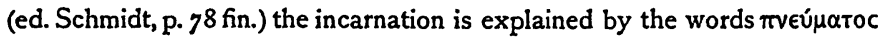

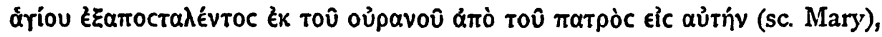

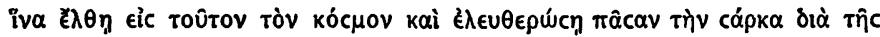

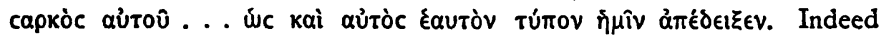
we may say generally, that early Roman Christology was realist, empirical, a posteriori in attitude, starting from the Christ of history; while that of the Greek East was idealistic, speculative, a priori, starting from a Divine being belonging to the supreme spiritual order ( $\pi v \in \hat{u} \mu \alpha$ ), who by appearing on earth in Judaea revealed the Unknown Father and brought incorruption to man, else in bondage to his sensuous corruptible nature (cápz). Of the latter type Alexandria was the head-quarters, as it had been of philosophic Jewish Hellenism, which had so much to do with preparing the soil for Gentile Christianity. Hence, as we have shown that 2 Clem. is a typical product of this Eastern type of Christology and its related religious philosophy, it is 
most natural to look for its original home in Alexandria, at a date c. $130 \pm$.

Against this conclusion no valid internal evidence ${ }^{x}$ seems to exist. But as hitherto the external evidence las been supposed to point strongly to Corinth or Rome, we must try to show that this too favours Alexandria at least as well as either of those cities. To begin with, all the external cvidence, both MSS and testimonia, is Eastern or directly dependent on Eastern witness. Rufinus and Jerome simply ccho Eusebius' language as to its non-acceptance, in such a way as to add to the force of the fact that it does not seem ever to have been translated into Latin. Next we observe that its earliest favourable witness is an Alexandrine Biblical MS in which it appears along with I Clem. as an appendix to the New Testament. Further, although the other and much later Greek MS (to which, along with the Syriac version appended to the New Testament in what purports to be the Harclean recension, we owe our knowledge of the entire homily) is the famous Jerusalem codex in which the Didache come to light, and therefore does not itself belong to Alexandria; yet it is quite likely that its archetype for the two Clementine 'Epistles' (as well as Barnabas, which here precedes them, and perhaps the Didache too) was of Alexandrine origin. That is, the centre of diffusion in the East for 2 Clem., if not for I Clem. also, ${ }^{2}$ was probably Alexandria: and in any case it was there $^{3}$ that it had the highest, i. e. quasi-canonical honour. This does not seem to favour Lightfoot's view that Alexandria was only the second home of both Clementine 'Epistles'. For assuming with him that the homily was originally delivered in Corinth, considerable time would elapse before its true nature and origin were forgotten and it became assigned to Clement as a second epistle of his, and that too in the face of its own internal evidence. Yet it was only as an epistle

I Lightfoot, it is true, laid much, indeed undue stress upon the phrase elc toùc

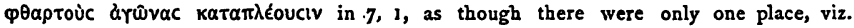
Corinth, where such a reference would be fally appropriate. He seems to forget that in the second century $A$. D. there were important games at a city like Alexandria.

2 According to Zabn (Grundrib der G. N. T. K., p. 23) its use spread 'probably first to Alexandria, later to the Syrians', which seems equally true of both writings.

3 So Zahn, loc. cil. 'Wahrscheinlich bezieht sich auf diese Briefe, was von kirchlicher Reception zweier Clemensbriefe bei den Kopten überliefert ist (Assemani Bibl. or. II, 14)'. See Lightfoot, Clement, I, 372 ff. for the Coptic form of the 85th Apostolical Canon, in both the Bohairic and Sahidic versions, as agreeing with the local estimate of both epistles implied in Cod. Alex.; so also with the Arabic versions of this canon. 
that it could be attributed to Clement of Rome: as long as its character as a homily was kept in mind, the thought of his authorship could not arise at Corinth. So it could not reach Alexandria in its false character at a date consistent with its establishing itself there in a quasi-canonical position. The only satisfactory hypothesis, on this score also, is that it became attached to I Clement, already in honour in the Alexandrine Church, soon after its orvn delivery c. 130士; and thus the confusion arose in Alexandria, its own home, in the course say of the third century. First it became regarded as another writing (homily) of Clement's, and subsequently per incurian (on the part of a copyist) as a second epistle of his.

Not only do external and internal evidence, as cited above, support the theory here set forth. Constant study of the homily viewed in this light will be found to confirm it in a hundred little details. This at least is the present writer's experience since the time when, nearly a year ago, he embodied it in a paper read before the Oxford 'Society of Historical Theology'; and he now desires to submit it to like testing by Fachmänner in the wider circles to which this journal appeals. 